\title{
Liberty and Security
}

\author{
Anmeldelse af Søren Friis
}

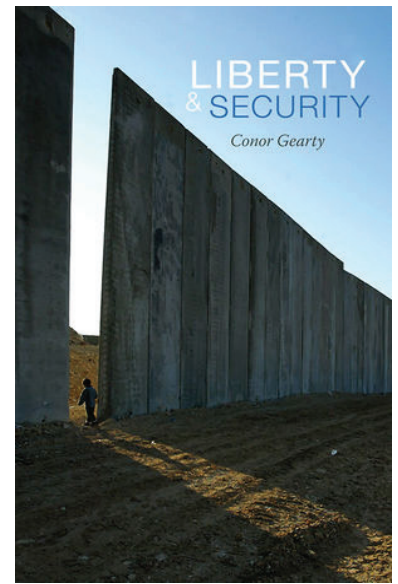

Conor Gearty: Liberty and Security, Cambridge: Polity Press, 2013

"In meeting those threats [against our nation], we have to strike the right balance between protecting our security and preserving our freedoms." Barack Obama, USA's præsident, 9. august 2013 (White House, 2013).

I kampen mod onde mennesker med onde hensigter handler det om at finde den rette balance mellem frihed og sikkerhed. Erklæringer af denne art er ofte blevet fremført af vestlige regeringer, senest i lyset af afsløringen af NSA's globale overvågningspro-

Søren Friis, ph.d.-stipendiat

Institut for Kultur og Samfund, Aarhus Universitet (friis@cas.au.dk) grammer i juni 2013. I diskussionen om den danske terrorlovgivning har spørgsmålet om "balancen" mellem netop disse to værdier ligeledes haft en central placering.

Conor Geartys Liberty and Security sætter alvorlige spørgsmålstegn ved den fremherskende opfattelse, at forholdet mellem frihed og sikkerhed virkelig er et spørgsmål om "balance" (se også Waldron, 2003). For Gearty, professor i menneskerettigheder ved London School of Economics, er problemets kerne, at essensen af frihed som en universel idé går tabt, når denne frihed undermineres for at opnå sikkerhed for de få. Derfor argumenterer han for, at de to begreber i stedet er nøje afhængige af hinanden. I sin korte bog præsenterer Conor Gearty en række eksempler på, at den globale krig mod terror(isme) siden 11. september 2001 har betydet, at "outsideres" frihed og sikkerhed er blevet ofret. Bogen er for så vidt et overbevisende indlæg imod den fremherskende, praktiske forståelse af de to begrebers forhold efter $9 / 11$. Gearty skitserer to forbundne udviklinger: Én, hvor terrorbekæmpelse er blevet et redskab til at nægte mange (eller bestemte) mennesker frihed og sikkerhed, og én, hvor anti-terrorens sprog er blevet "globaliseret" og således kapret af både demokratiske og autoritære regimer til at slå ned på intern uro og politisk modstand, selv når denne har været af åbenlys ikke-terroristisk karakter (se også Gearty, 2006; Gearty, 2007).

Det er klart fra første side, at Gearty med Liberty and Security sigter mod at kombinere jura, retsetik og be- 
grebsanalyse. Det bliver dog hurtigt åbenbart, at forfatterens hensigt ikke er at nå frem til fyldestgørende definitioner på begreberne, men snarere at behandle nutidens spændingsfyldte forståelser af frihed og sikkerhed som et prisme, hvorigennem det er muligt at skue deres sande potentiale:

"This book is about the shape that these words have taken through time and from place to place, how much they have been realized and for how many, and what their standing is today. What mainly occupies us here is not their core meaning so much as it is the reach of the benefits that each so powerfully evokes. It is the 'for how many' issue that mainly concerns us: to whom are liberty and security to be extended? Is it to be to all or just the few?" (Gearty, 2013, s. 2)

Selvom de første sætninger foroven antyder et projekt af enorm størrelse, lægger Gearty i praksis et noget mere begrænset snit, hvor han retter spørgsmålet om "frihed og sikkerhed for hvem?" mod den politiske samtid. De globale konsekvenser af USA's reaktion på angrebene 11 . september 2001 er nok i store træk velkendte for de fleste læsere, men af indlysende grunde udgør disse alligevel et centralt element i fortællingen her. En af Geartys pointer er, at svaret på terroraktionerne i 2001 har været fokuseret på behovet for frihed og sikkerhed for $o s$, mens disse goder i praktisk forstand er blevet nægtet dem, dvs. outsiderne. Disse "os og dem"-størrelser er noget uklart definerede i bogen: I de fleste af Geartys eksempler er der dog tale om borgere i muslimske lande, hvor krigen mod terror i særlig grad har raset. I Geartys tolkning har der på denne vis fundet en form for kulturelt defineret krigsførelse sted, hvor amerikanske allierede såsom Storbritannien - og Danmark, kunne man tilføje - entusiastisk har deltaget.

Bogens måske mest afgørende bidrag er to centrale kapitler, som skitserer den dramatiske juridiske reaktion på angrebene 11. september 2001. Vinklen er decideret international og historien er derfor noget mindre velkendt end historien om den amerikanske respons. Gearty begynder ved en bemærkelsesværdig beslutning vedtaget i FN's Sikkerhedsråd 28. september 2001, resolution 1373. I denne resolution forpligtede Sikkerhedsrådet for første gang alle FN's medlemsstater til at handle mod "terrorisme" (og støtte til terrorisme) på en række måder. Her var der på trods af terror-terminologiens uklarheder ikke tale om anbefalinger eller rettesnore: Resolutionen henviste derimod håndfast til kapitel $7 \mathrm{i}$ FN-pagten, som giver mulighed for at gennemføre Sikkerhedsrådets beslutninger med militær tvang.

En række opfølgende beslutninger i Sikkerhedsrådet fulgte i årene efter. Rådet styrkede bl.a. sin nye position som central håndhæver af den globale terrorbekæmpelse (omend lidet anerkendt i den vestlige offentlighed) ved i 2004 at oprette et permanent "Counter-Terrorism Executive Committee Directorate". Efter bombningerne i London 7. juli 2005 udvidede Sikkerhedsrådet - med Danmark som medlem i denne periode - igen de statslige forpligtelser i kampen mod terror til at omfatte indefrysningen af midler, der tilhørte al-Qaeda, Osama bin Laden og Taleban-bevægelsen. Sikkerhedsrådet tilføjede desuden enhver gruppe eller person, som mentes at være "associeret" eller på nogen måde støtte disse tre organisationer/personer, til listen over antiterrorens mål (UNDPI, 2005).

Selvom FN's Sikkerhedsråd på denne måde udnyttede sin ret til at insistere på national lovgivning, som skulle modvirke terrorisme, forsømte organet at udstede nogen egentlig vejledning om, hvad "terrorisme" faktisk kunne tænkes at betyde. Man gjorde sig heller ingen videre overvejelser om, hvordan den nye antiterror-lovgivning forholdt sig til centrale FNprincipper såsom menneskerettigheder og retfærdighed. Døren var således blevet åbnet på vid gab for autoritære regeringer i lande såsom Kina, Rusland, Hviderusland og Kasakhstan - mange af dem "allierede" i USA's kamp mod terror - som frit kunne kapre sproget om "terrorisme" til at undertrykke deres egne borgere. Så sent som oktober 2011 lovfæstede Kina f.eks. en juridisk gummidefinition på terrorisme, hvor alle aktiviteter med den hensigt at "destabilisere den sociale orden" hørte under. I forbindelse med denne lovs vedtagelse fulgte en (ironisk) henvisning til, at der stadig manglede en international definition på "terror" at støtte sig til, hvilket de kinesiske magthavere altså søgte at afhjælpe på deres egen drakoniske måde (Gearty, 2013, s. 52).

Det var dog ikke kun autoritære regimer, som aktivt forsøgte at fylde terrorisme-hullerne til kanten og længere endnu. En ordlyd lignende den kinesiske findes også i den danske straffelovs $§ 114$, den såkaldte terrorparagraf, som blev revideret i 2002 
og 2006. Her indkredses "terrorisme" først til at omfatte en række bestemte handlinger, som i forvejen er strafbare, heriblandt alt fra drab til forstyrrelse af trafiksikkerheden. Derefter følger en langt mere elastisk ordlyd: Personer og grupper, som vurderes at have ydet "væsentlig støtte" til andres aktiviteter, når disse har haft til hensigt at forstyrre samfundsordenen, kan ligeledes straffes under $§ 144$ (dette omfattede også nyhedsmedier, som Højesterets endelige kendelse mod kurdisk-danske Roj-TV viste i 2014). Da VK-regeringen med sin anden "anti-terrorpakke" fra 2006 udvidede paragraffen yderligere i denne retning, mødte dette bl.a. skarp kritik fra Advokatrådet, Datatilsynet, Forbrugerrådet, den liberale tænketank CEPOS og Institut for Menneskerettigheder, som bl.a. advarede om, at terrorpakken trak Danmark i retning af et kontrol- og overvågningssamfund (se også Dyrn, 2009).

Gearty gør også opmærksom på en beslægtet konsekvens af terrorlovgivningen, nemlig den økonomiske "blacklisting" af individer under rammerne af FN's terrorbekæmpelsesregime. Om denne proces, som ofte kan forekomme vilkårlig og uigennemsigtig, konkluderer han således: "Naturally no person of any influence or importance in the process thought for one moment that any person like themselves - much less somebody they knew - would be likely to find themselves pitched into this legal black hole; taking their own liberty for granted, their consuming interest was with their own (and their own kind's) security" (Gearty, 2013, s. 38).

I bredere forstand ser Gearty et skred i retning af en post- eller neo-demokratisk regeringsmodel hvor de præ-demokratiske betydninger af frihed og sikkerhed - hovedsageligt tilpasset de få - har fået et comeback (Gearty skelner ikke decideret mellem post- og neodemokrati; for en kritik af disse begreber se Müller 2012). Liberty and Security er således et normativt indgreb: Ifølge Gearty er det afgørende med en nyfortolkning af disse begreber, så de igen bevæger sig mod en ægte universel betydning. Det virker dog noget uklart, om en sådan omfortolkning vil ændre på en dynamik, hvor eliter antageligt vil og kan bruge begreberne til at fremme egne interesser. Alligevel slår Gearty en optimistisk tone an ved at hævde, at den erkærede støtte til demokrati, menneskerettigheder og retsstaten er forblevet så rodfæstet i det neo-demokratiske sprog, at de bagvedliggende idéer ikke blot kan tilsidesættes: Med andre ord rummer demokratiets sprog i sig selv arsenalet for modstanden mod skindemokratiet.

Bogens juridiske fokus efterlader i sagens natur en række andre vinkler på emnet noget underbelyste. Gearty bemærker f.eks. ikke de slående kontinuiteter, som på trods af den nye kamp mod terror efter 9/11 findes i den vestlige sikkerhedspolitik før og efter 2001. Liberty and Security konfronterer heller ikke "sikkerhed" som et begreb, der netop er politisk ladet og som derfor uvægerligt anvendes med politiske mål for øje. I stedet foretrækker Gearty at betragte sikkerhed som et ideal, som i sidste ende kan opnås, hvis blot begrebets indhold forstås korrekt. Han sætter derfor sin lid til en "menneskelig sikkerhed", hvor beskyttelsen af kernefriheder kombineres med beskyttelsen af individet fra sociale, økonomiske og miljømæssige trusler (Burgess og Owen, 2004; Tadjbakhsh og Chenoy, 2007). Gearty overvejer ikke den mulighed, at en udvidelse af rammerne for sikkerhedspolitikken - selv i "menneskelig" retning - meget vel kan have negative konsekvenser, bl.a. fordi "sikkerhed" som normativt begreb ofte går hånd $i$ hånd med offensive, militære fremgangsmåder (se Wæver, 1997; Neocleous, 2007).

Disse mangler burde ikke aflede opmærksomheden fra Geartys velformulerede indspark i debatten om "den svære balancegang" mellem sikkerhed og frihed - en balancegang, som måske slet ikke er nogen balancegang og måske slet ikke burde være så svær, hvis man følger forfatteren. Geartys indgreb i den samfunds- og forskningsmæssige debat er uden tvivl rettidig i lyset af udviklinger såsom Edward Snowdens afsløringer af global overvågning, fremkomsten af cyberkrigsførelse mellem stater, udvidelsen af USA's program for såkaldt "målrettede drab" i andre lande og tendensen til en militariseret respons på politiske demonstrationer i de vestlige lande. Disse bekymrende nyskabelser rejser dog samtidig spørgsmålet om, hvorvidt kampen nu vitterligt foregår mellem "os og dem" eller om den snarere foregår mellem magthavere og subjekter.

På trods af sådanne usikkerheder giver de seneste års udvikling en del vægt til Conor Geartys tese om, at der må findes en stærkere og mere holdbar forståelse af forholdet mellem frihed og sikkerhed. Udviklingen illustrerer nemlig, at den modsatte mulighed bestemt eksisterer i bedste velgående. 


\section{Referencer}

Burgess, JP \& Owen, T (red.) (2004). Special Section: What Is "Human Security"? Security Dialogue, 35 (3), 345-387.

Dyrn, G (2009). Retssikkerhed: Begreb og indhold i forandring. Besvarelse af Advokatsrådets Prisopgave 2009. Lokaliseret 1.8.2014 på WWW: http:// www.advokatsamfundet.dk/Service/English/Publications/ /media/Engelsk/Prisopgave 2009 Gert Dyrn 3 versiondoc.ashx.

Gearty, C (2006). Can Human Rights Survive? Cambridge: Cambridge University Press.

Gearty, C (2007). Civil Liberties. Oxford: Oxford University Press.

Gearty, C (2013). Liberty and Security. Cambridge: Polity Press.

Müller, JW (2012). Postdemokratiet og den politiske afmagt. Information, 17.12.2012, 19.

Neocleous, M (2007). Security, Liberty and the Myth of Balance: Towards a Critique of Security Politics. Contemporary Political Philosophy, 6 (2), 191-210.
Tadjbakhsh, S \& Chenoy, AM (2007). Human Security: Concepts and Implications. Abingdon: Routledge.

UNDPI (2005). Security Council Extends Sanctions against Al-Qaida, Taliban; Reiterates Need for Close Cooperation among Subsidiary Committees, 29 July 2005. Lokaliseret 1.8.2014 på WWW: http://www. un.org/News/Press/docs/2005/sc8468.doc.htm.

Waldron, J (2003). Security and Liberty: The Image of Balance. Journal of Political Philosophy, 11 (2), 191-210.

Wæver, O (1997). Concepts of Security. København: Institut for Statskundskab.

White House (2013). Remarks by the President in a Press Conference, 9 August 2013. Lokaliseret 1.8.2014 på WWW: http://www.whitehouse.gov/ the-press-office/2013/08/09/remarks-president-pressconference. 